\title{
Retos y cambios en el equipo editorial de la revista
}

\author{
Mario Delgado-Noguera ${ }^{1}$
}

Con este número completamos el volumen 21 de la Revista de la Facultad Ciencias de la Salud. Sostenerla ha significado un esfuerzo continuo desde su fundación en 1998 por parte de Alfonso Tenorio. La publicación ha tenido altibajos, como es común en las publicaciones periódicas universitarias, que no solamente dependen del esfuerzo y la mística de un grupo de profesionales de la salud motivados por su deseo de dar a conocer los resultados de investigación principalmente de las regiones y departamentos como el Cauca. También han dependido de la política cambiante de Colciencias y de su sistema de indexación Publindex, en un contexto global volátil y en crisis (1). Muchos consideran que es una politica ernática que: "sin reconocer el conocimiento de la disciplina copia modelos de la ciencia natural con influencia fuerte de modelos corporativos como Scimago y Scopus" (2).

Sabemos que esta búsqueda de modelos de indexación es a la vez una búsqueda para desarrollar nuestro propio conocimiento regional y nacional, que algunos llaman una curaduría del mismo y su acervo. En el ámbito de la salud esto es relevante porque estamos en un país tropical con enfermedades en medio de un panorama de postconflicto, una transición demognáfica con envejecimiento de la población, un sistema de salud que cae en continuas crisis, entre los problemas más visibles para resolver desde el punto de vista de la salud pública. Sin embargo, el equipo editorial de la Revista, con el apoyo de los directivos de la Universidad del Cauca, persiste en este esfuerzo por diseminar nuestra producción académica, y de paso formar profesionales de la salud en el campo de la edición que tiene, como se ha anotado, sus particularidades (3). Personalmente, aunque permanezco en el Comité Editorial, dejo el cargo de Editor jefe de la Revista con la confianza que me da un entusiasta equipo joven de epidemiólogos y educadores que persistinán con ahínco en dar a conocer nuestra publicación, ampliar la cultura de la escritura, velar por la calidad de los artículos y de la investigación que se produce en nuestra área de influencia (4). La Revista dejaná de publicarse físicamente, siguiendo una tendencia general, y estaná

1 Editor jefe. Revista de la Facultad de Ciencias de la Salud de la Universidad del Cauca 
en el portal, que ha sido rediseńado en el sistema OJS (Open Journal System) para dar mayor facilidad a los editores y autores.

En la pasada convocatoria de Colciencias para la indexación de revistas nacionales de 2018, logramos cumplir con todos los requisitos excepto el nivel de citación o H5, lo que nos costó quedar excluidos del sistema. No obstante, al no quedar clasificados sentimos un aire de libertad que nos permite ir más allá de los criterios restrictivos del Publindex que no permite salir de un círculo vicioso donde peligra la calidad de los contenidos. Confiamos en el avance de una política real universitaria para las publicacionesperiódicas que garantice institucionalmente la persistencia de la Revista y favorezca la aparición de publicaciones periódicas universitarias. La Universidad se verá favorecida pues su producción académica tendrá mayor amplitud, estimulaná la crítica y contań con medios que validarán los hallazgos científicos.

En cuanto a nuestra Revista, no solamente el equipo editorial debe persistir en dar a conocerla y difundirla, sino que es una tarea constante de todos los académicos de la Facultad y de la Universidad.

\section{REFERENCIAS}

1. Delgado-Noguera M. Editorial: Investigación, región y dependencia. Rev. Fac. Cienc. Salud Univ. Cauca 2013;15(4):9-10. Disponible en: https://revistas.unicauca.edu.co/ index.php/rfcs/article/view/39

2. Tejada-Goméz, MA, Los sistemas de indexación. Alcances y limitaciones de la política de Publindex, Unilibros de Colombia, 26a edición, 2019.

3. Delgado-Noguera M. Editorial. Necesidades de formación de los editores de revistas biomédicas. Rev. Fac. Cienc. Salud Univ. Cauca 2018;20(1):14-7. Disponible en: https:// revistas.unicauca.edu.co/index.php/rfcs/article/view/934

4. Calvache JA. Editorial: Mejorando el reporte de la investigación a través de las indicaciones a los autores. Rev. Fac. Cienc. Salud Univ. Cauca 2017;19(1):16-9. Disponible en: https://revistas.unicauca.edu.co/index.php/rfcs/article/view/164 


\title{
Challenges and opportunities of our journal
}

\author{
Mario Delgado-Noguera ${ }^{1}$
}

With this number we complete the volume 21 of the Revista de la Facultad de Ciencias de la Salud de la Universidad del Cauca. Sustaining it has meant a continuous effort since its foundation in 1998 by Alfonso Tenorio. The publication has had ups and downs, as is common in university publications, which not only depend on the effort of a group of health professionals motivated by their desire to publish research results mainly from regions and departments like Cauca. They have also depended on the changing policy of Colciencias and its Publindex indexing system, in a volatile global context and in crisis (1). Many consider it an erratic policy that: "without recognizing the knowledge of the discipline, copy models of natural science with strong influence of corporate models such as Scimago and Scopus" (2).

We know that this search for indexing models is both a search to develop our own regional and national knowledge. In the field of health this is relevant because we are in a tropical country with diseases in the midst of a post-conflict scenario, a demographic transition with population aging, a health system that falls into continuous crises, among the most visible problems to be solved from the point of view of public health. However, the editorial team of the journal, with the support of the University of Cauca, persists in this effort to disseminate our academic production, and train health professionals in the field of the edition (3).

Personally, although I remain in the Editorial Committee, Ileave the position of Editor-inChief of the journal with the confidence that an enthusiasticyoung team of epidemiologists and educators will determinedly persist in making ourpublication known, expanding the culture of writing and ensure the quality of the articles and research that takes place in our area of influence (4). The journal will stoppublishing physically, following a general trend, and will be on the portal, which has been redesigned in the OJS (Open Journal System) system to give publishers and authors greater access.

In the last call of Colciencias for the indexation of national journals of 2018, we meet all the six required criteria except the citation level or $\mathrm{H} 5$ index, which cost us to be excluded from the system. However, by not being classified, we feel an air of freedom

1 Editor-in-chief. Revista de la Facultad de Ciencias de la Salud de la Universidad del Cauca. 
that allows us to go beyond the restrictive criteria of Publindex that does not allow us to leave a vicious circle that does not always guarantee the quality of the contents. We rely on the advancement of a real university policy for periodical publications, which institutionally encourages the permanence of the journal and favors the appearance of new university journals.

Not only the editorial team should persist in making our journal known, but it is a constant task of all academics of the Faculty and the University.

\section{REFERENCES}

1. Delgado-Noguera M. Editorial: Investigación, región y dependencia. Rev. Fac. Cienc. Salud Univ. Cauca 2013;15(4):9-10. Disponible en: https://revistas.unicauca.edu.co/ index.php/rfcs/article/view/39

2. Tejada-Goméz, MA, Los sistemas de indexación. Alcances y limitaciones de la política de Publindex, Unilibros de Colombia, 26 a edición, 2019.

3. Delgado-Noguera M. Editorial. Necesidades de formación de los editores de revistas biomédicas. Rev. Fac. Cienc. Salud Univ. Cauca 2018;20(1):14-7. Disponible en: https:// revistas.unicauca.edu.co/index.php/rfcs/article/view/934

4. Calvache JA. Editorial: Mejorando el reporte de la investigación a través de las indicaciones a los autores. Rev. Fac. Cienc. Salud Univ. Cauca 2017;19(1):16-9. Disponible en: https://revistas.unicauca.edu.co/index.php/rfcs/article/view/164 